treated mechanically.

Frightening away birds and seals of threatened places seems to be very unsuitable. In most cases the clean-up of oiled birds and seals is also little effective from the point of view of conservation of the population.

\title{
References
}

Baker, J. M., 1976. Marine ecology and oil pollution. Proceedings 'Marine ecology and oil pollution' (Aviemore, Scotland, 1975). John Wiley, New York, 556 pp.

Gundlach, E. R. \& M. O., Hayes, 1978. Vulnerability of coastal environments to oil spill impacts. Marine Technology Society Journal 12: 18-27.

McCarthy, L. T., G. P. Lindblom \& H. F. Walter, 1978. Chemical dispersants for the control of oil spills. Symposium American Society of Testing of Materials, Technical Publication 65, $507 \mathrm{pp}$.

This synopsis is based on a report entitled 'Gedrag, bestrijding en biologische effecten van olie in estuariene gebieden', Vol. 1. 'Literatuuroverzicht' (Literature review), 2 parts, 420 pp., 39 figs., 125 tables, 62 pp. of references; Vol. 2. 'Olie in de Waddenzee' (Oil in the Wadden Sea), 97 pp., 6 figs., 9 tables, 169 refs. RIN-Rapport 82/18 and 83/22, Research Institute for Nature Management (RIN), Arnhem/Leersum/ Texel, 1982/83. Dutch.

Available as paper copy (order R034P, $f 62.35$ (three parts) including postage) or on microfiche (order R034M, f37.50 including postage) at: NARD, clo Pudoc, P.O. Box 4, 6700 AA Wageningen, Netherlands (telex 45015 blhwg nl.)

Netherlands Journal of Agricultural Science 33 (1985) 81-84

\section{Acclimatization of anaerobic sludge for UASB reactor start-up}

\author{
W. J. de Zeeuw (AVEBE B.A., P.O. Box 15, 9640 AA Veendam, Netherlands) \\ Received 16 November 1984; accepted 17 January 1985
}

\begin{abstract}
The operation of UASB reactors during the initial start-up period was studied with unadapted seed material. Different types of sludge granules developed depending on the start-up conditions and the type of seed sludge used.

Keywords: anaerobic wastewater treatment, UASB reactor, start-up, granular sludge, biogas.
\end{abstract}

Introduction. The Upflow Anaerobic Sludge Bed (UASB) reactor represents a high-rate anaerobic wastewater treatment system (Lettinga et al., 1980). Most of the active biomass in the reactor is present in the form of sludge granules which possess excellent settling properties. If no acclimatized (granular) sludge is available, 
the first start-up of a UASB reactor is performed with unadapted seed material. Such a start-up frequently causes specific problems - such as excessive sludge washout - and may be time-consuming. The subject of this study is the operation of UASB reactors during the initial start-up period with digested sewage sludge as seed material and volatile fatty acids (VFA) as substrate.

Material and methods. The experiments were performed in 5-litre intermittently stirred batch reactors and in $20-30$ litre UASB reactors at $30^{\circ} \mathrm{C}$. The feed solution contained approximately equal amounts of acetate, propionate and occasionally butyrate.

Digested sewage sludge was chosen as seed material, because it is readily available in industrialized countries and contains a rich variety of anaerobic bacteria. The larger part of its volatile suspended solids (VSS) consists of refractory material instead of biomass. In order to determine the methanogenic activity of digested sewage sludge a standardized batch-fed activity test was used (sludge concentration $2.5 \mathrm{~kg}$ VSS per $\mathrm{m}^{3}$; substrate concentration $2.6 \mathrm{~kg}$ VFA-COD per $\left.\mathrm{m}^{3}\right)$. The methanogenic activity of samples from 8 different sewage sludge digesters ranged from 0.08 to $0.2 \mathrm{~kg} \mathrm{CH}_{4}$-COD per kg VSS per day. Frequently lag phases occurred.

The start-up procedure of the UASB reactors consisted of a stepwise increase of the loading rate whenever the COD removal efficiency surpassed 80 to $90 \%$.

Results and discussion. A correlation was found between the original dry suspended solids (DSS) concentration of digested sewage sludge as obtained from the different sludge digesters and factors relevant to UASB reactor start-up, notably the VSS content, the settleability and the methanogenic activity. One extreme is concentrated digested sewage sludge ( $\geqslant 75 \mathrm{~kg}$ DSS per $\mathrm{m}^{3}$ ), which is inhomogeneous with respect to the settling characteristics. A large fraction (more than 20\%) of the VSS of concentrated digested sewage sludge will wash out from the UASB reactor during the first week of start-up. The fraction of the sludge which is retained exhibits a relatively good settleability (Sludge volume Index (SVI) of approximately $40 \mathrm{ml}$ per g DSS) and a relatively low specific methanogenic activity. The other extreme is dilute digested sewage sludge $\left(\leqslant 40 \mathrm{~kg}\right.$ DSS per $\left.\mathrm{m}^{3}\right)$. This sludge is much more homogeneous with respect to settleability and little sludge wash-out (less than $6 \%$ of the VSS) will occur during the initial stage of reactor start-up. The retained sludge exhibits a relatively low settleability (SVI of approximately $100 \mathrm{ml}$ per g DSS) and a relatively high specific methanogenic activity.

The average sludge growth yield for the digestion of VFA was $0.022 \mathrm{~g}$ VSS per $\mathrm{g}$ COD in batch experiments as well as in UASB reactor experiments. The predominant bacterial population resembled Methanothrix (Zehnder et al., 1980). The specific methanogenic activity of newly formed sludge-VSS was determined to be 2.9 $\mathrm{kg} \mathrm{CH}_{4}-\mathrm{COD}$ per kg VSS per day. From the corresponding growth rate $\mu=2.9 \times$ $0.002=0.064 \mathrm{~d}^{-1}$ the theoretical minimum start-up time of a UASB reactor treating VFA and seeded with digested sewage sludge can be predicted to be approximately 35 days (assuming complete biomass retention and an initial average activity of $1 \mathrm{~kg}$ $\mathrm{CH}_{4}-\mathrm{COD} \mathrm{m}{ }^{-3} \mathrm{~d}^{-1}$, and defining reaching an activity of $10 \mathrm{~kg} \mathrm{CH}_{4}-\mathrm{COD} \mathrm{m}{ }^{-3} \mathrm{~d}^{-1}$ as 


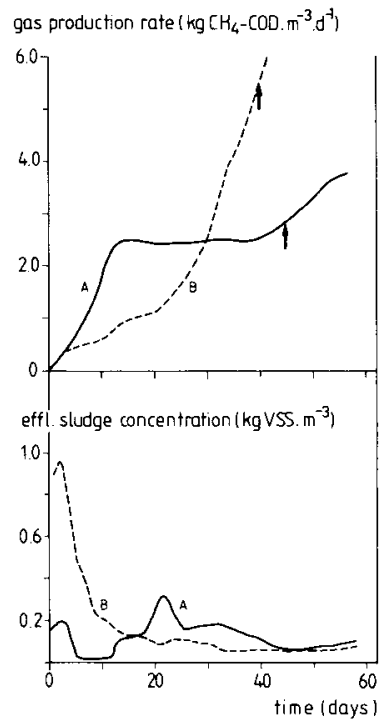

Fig. 1. Gas production rate and effluent sludge concentration during start-up of UASB reactors seeded with different types of digisted sewage sludge.

A. Seeded with $10 \mathrm{~kg} \mathrm{VSS} \mathrm{m}^{-3}$ of sludge with an original concentration of $43.5 \mathrm{~kg} \mathrm{DSS} \mathrm{m}^{-3}$. Predominantly sludge bed expansion washout.

B. Seeded with $11.5 \mathrm{~kg} \mathrm{VSS} \mathrm{m}^{-3}$ of sludge with an original concentration of $79 \mathrm{~kg} \mathrm{DSS} \mathrm{m}^{-3}$. Predominantly sludge bed erosion wash-out.

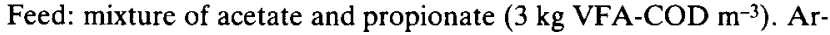
rows indicate the appearance of macroscopic sludge granules.

the end of reactor start-up). In practice the start-up time is longer, i.e. 60 to 80 days, because of sludge wash-out.

The sludge wash-out from UASB ractors was examined in relation to the type and amount of seed sludge supplied. Two types of sludge wash-out are distinguished: sludge bed erosion wash-out and sludge bed expansion wash-out. Sludge bed erosion wash-out represents an essential feature of the UASB concept, i.e. the selection process based on differences in the settleability of the sludge particles. Washed out sludge should not be returned into the reactor, because this adversely interferes with the selection process. Sludge bed expansion wash-out predominantly occurs when using a dilute digested sewage sludge in the treatment of medium strength wastewaters (3-6 $\mathrm{kg} \mathrm{COD} \mathrm{m}^{-3}$ ). It involves little selection between sludge particles with a different settleability, and greatly reduces the average biomass retention time in the reactor. By choosing a concentrated digested sewage sludge as seed the latter type of sludge wash-out can be avoided, i.e. as long as the amount of seed sludge is small enough - 10 to $15 \mathrm{~kg} \mathrm{VSS} \mathrm{m}^{-3}$ - to maintain the sludge bed beneath the settler compartment during the start-up period.

The average biomass retention time during the initial stages of reactor start-up turned out to determine the type of sludge granules that develop. The first macroscopic sludge granules are normally observed after 30 to 45 days. A long biomass retention time in the reactor permits conglomerates of bacteria to grow out to well settling particles, and results in the development of granules predominantly consisting of densely packed Methanothrix bacteria (Fig. 1; case B).

At short biomass retention times during the initial stage of start-up bacterial conglomerates are wasted before they can grow out to form granules. In that case sludge granules develop through bacterial attachment to well-settling, inert carrier

Neth. J. agric. Sci. 33 (1985) 
particles originating from the seed sludge. These granules consist mainly of loosely intertwined filaments of Methanothrix (Fig. 1; case A).

The development of bulking anaerobic sludge is reinforced by seeding with a dilute digested sewage sludge type $\left(\leqslant 40 \mathrm{~kg} \mathrm{DSS} \mathrm{m}^{-3}\right)$. This will prolong the start-up time, because the flocculent sludge will wash out at higher loading rates.

In the treatment of a high-strength wastewater the dilution rate is low during the initial stages of start-up. Little selection pressure is exerted on the sludge particles and dispersed bacterial growth occurs. Consequently it will take a relatively long time before sludge granules develop.

In contrast, the treatment of low-strength wastewater is accompanied by relatively strong sludge bed erosion wash-out and consequently a high selection pressure, leading to a rapid development of sludge granules.

\title{
References
}

Lettinga, G., A. F. M. van Velsen, S. W. Hobma, W. de Zeeuw \& A. Klapwijk, 1980. Use of the Upflow Sludge Blanket (USB) reactor concept for biological wastewater treatment, especially for anaerobic treatment. Biotechnology and Bioengineering 22: 699-734.

Zehnder, A. J. B., B. A. Huser, T. D. Brock \& K. Wuhrmann, 1980. Characterization of an acetate decarboxylating, non-hydrogen-oxidizing methane bacterium. Archives of Microbiology 124: 1-11.

This synopsis is based on a doctoral thesis, Agricultural University, Wageningen, 1984. viii +157 pp., 52 figs., 59 tables, 165 refs. English, Dutch summary.

Available as paper copy (order R026P, $f 30$ including postage) or on microfiche (order R026M, f 17.50 including postage) at: NARD, clo Pudoc, P.O. Box 4, 6700 AA Wageningen, Netherlands (telex 45015 blhwg $\mathrm{nl}$ ).

\section{Single-trait and multiple-trait models for sire evaluation in a population under selection}

J. H. J. van der Werf (Department of Animal Breeding, Agricultural University, Marijkeweg 40, 6709 PG Wageningen, Netherlands)

Received 23 November 1984; accepted 23 January 1985

\begin{abstract}
A population was simulated with a selection process implemented. Single- and multiple-trait mixed models for sire evaluation were used to try to account for selection by comparing sire predictions on unbiasedness. Only complete multiple-trait models yielded unbiased sire predictions, both for traits directly selected for and correlated traits.
\end{abstract}

